\title{
Studi Komparatif Upaya Penanganan Malapraktik Medis dalam Proses Peradilan Pidana di Indonesia dan Amerika
}

\section{Comparative Study of Medical Malpractice Management Efforts in Criminal Justice Processes in Indonesia and America}

\author{
Fitriah Faisal1, Rahman Hasima², Ali Rizky ${ }^{3}$ \\ 1. Universitas Halu Oleo, Indonesia. E-mail: fitriahfaisal@uho.ac.id \\ 2. Universitas Halu Oleo, Indonesia. E-mail: rahmanhasima@uho.ac.id \\ 3. Universitas Halu Oleo, Indonesia. E-mail: $\underline{\text { alirizky76@gmail.com }}$
}

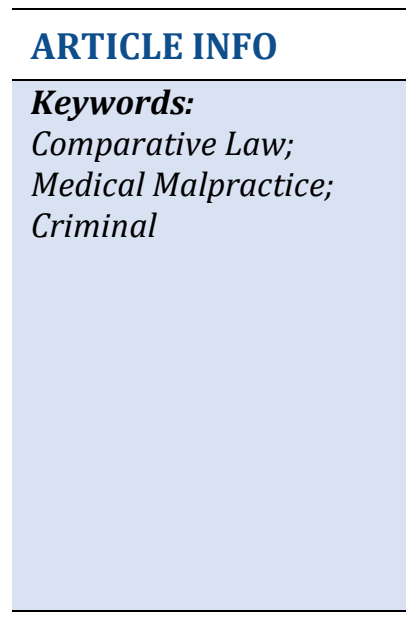

INFO ARTIKEL

\section{Kata kunci:}

Perbandingan Hukum; Malapraktik Medis;

Pidana

\begin{abstract}
The study is intended to comparative the law about an effort handling of medical malpractice in the process of criminal judicial system between Indonesia and the United States as one of the countries that was developing in the field of medical and technological medical. This study uses a normative legal research method with a comparative approach or legal comparison. The results of the study are known that proofing in malpractice cases in Indonesia in the same way as KUHAP. Proofing in the KUHAP adopted the system or theory of proof under the law negatively (negatively), while in the United States in resolving medical malpractice cases to apply the principle of res ipsa loquitur. In the United States there are no legal medical laws that apply to all countries. Each state has its own provisions in trying doctors. Some medical law instruments known in the United States are the Liability Act, Good Samaritan Law and Medico Legal Consideration.
\end{abstract}




\section{Pendahuluan}

Studi perbandingan hukum adalah suatu metode studi hukum yang mempelajari perbedaan sistem hukum antara negara yang satu dengan yang lainnya atau membandingkan sistem hukum antar negara. Rudolf D. Schlesinger dalam Soedjono Dirdjosisworo mengemukakan bahwa studi perbandingan hukum merupakan metode penyelidikan dengan tujuan untuk memperoleh pengetahuan yang lebih mendalam tentang bahan hukum tertentu. Selanjutnya menurut Sudarto dikatakan bahwa perbandingan hukum bukanlah suatu perangkat peraturan dan asas-asas hukum, atau suatu cabang hukum, melainkan suatu cara menggarap unsur hukum asing yang aktual dalam suatu masalah hukum. ${ }^{1}$

Studi perbandingan hukum pidana pada dasarnya memperbandingkan berbagai sistem hukum yang ada, dalam hal ini yang diperbandingkan adalah dua atau lebih sistem hukum yang berbeda. Hukum pidana positif Indonesia ialah berasal dari keluarga hukum Civil Law System yang mementingkan sumber hukum dari peraturan perundangan yang ada dan berlaku di Indonesia. Sementara Inggris menganut sistem hukum Common Law System yang mengutamakan kebiasaan yang berlaku di sana. Kebiasaan tersebut dapat berupa norma atau putusan-putusan hakim sebelumnya.

Malapraktik Medis menjadi sebuah isu yang belakangan terus dibicarakan di Indonesia, dimana dokter-dokter yang dianggap melakukan "Malapraktik" dikatakan "tidak tersentuh" oleh aturan hukum karena rumitnya pembuktian malapraktik medis dalam penegakkan hukum di Indonesia. Di negara Anglo Saxon, perkembangan hukum medis lebih maju daripada negara-negara common law, salah satunya adalah Amerika, Bahwa Amerika merupakan salah satu negara penganut sistem Anglo Saxon yang perkembangan praktik medisnya sangat besar dan juga perkembangan hukum mengenai medis atau kedokteran, begitu juga kasus Malapraktik medis di Negara ini. Amerika Serikat untuk tahun 2000 saja, terdapat 86.640 kasus tuntutan Malapraktik. ${ }^{2}$

Ilmu kedokteran berasal dari sumber yang sama yaitu Hypoccrates, maka cara yang dilakukan profesi kedokteran di mana pun baik Amerika maupun Indonesia adalah sama, yang membedakan adalah kemajuan pengetahuan dan teknologi . Di samping itu literatur hukum kedokteran di negara Anglo Saxon sudah banyak sedangkan di Indonesia masih baru berkembang, maka perbandingan hukum merupakan salah satu metode yang membantu dalam pengembangan hukum kedokteran khususnya di dalam pengembangan aturan, pembuktian dan pemidanaan pelaku yang terbilang sangat sulit dalam praktik di Indonesia. Sehingga, Dalam tulisan ini, ingin melihat Bagaimana Perbandingan Upaya

Soedjono Dirdjosisworo, Pengantar Ilmu Hukum (Jakarta: RajaGrafindo, 2010), 60.

Ardianingtyas dan Charles M. Tampubolon, "Kesalahan Diagnosis Dokter: Tergolong Malpraktek atau Kelalaian," HukumOnline.com, diakses November 2019 , https://www.hukumonline.com/berita/baca/hol10135/kesalahan-diagnosis-dokter-tergolongmalpraktek-atau-kelalaian-medikkah/. 
Penanganan Malapraktik Medis dalam Proses Peradilan Pidana di Indonesia dan di Amerika?

\section{Metode}

Penelitian ini menggunakan metode penelitian hukum normatif. Penelitian normatif yaitu penelitian yang dilakukan dengan cara meneliti bahan pustaka. Data yang digunakan dalam penelitian ini adalah data sekunder yang mencakup bahan hukum primer yaitu peraturan perundang-undangan, kemudian penelitian ini juga menggunakan bahan hukum sekunder, yaitu bahan hukum yang memberikan penjelasan mengenai bahan hukum primer, seperti hasil penelitian, hasil karya dari kalangan hukum. Penelitian ini juga menggunakan bahan hukum tersier seperti kamus Bahasa maupun kamus hukum. ${ }^{3}$ Penelitian ini dilakukan dengan metode pendekatan komparatif atau penelitian tentang perbandingan hukum baik mengenai sistem hukum antar negara maupun perbandingan produk hukum dan karakter hukum dalam suatu negara. ${ }^{4}$ Dalam penelitian ini yang menjadi alat utama pengumpulan data, berupa studi dokumen atau studi kepustakaan. Di dalam penelitian ini pengumpulan data dilakukan dengan metode studi kepustakaan, yaitu dilakukan dengan mengumpulkan, mengkaji dan mengolah literatur, peraturan perundang-undangan maupun artikel, jurnal dan karya ilmiah sebagai penunjang teori dalam penulisan serta pembahasan penelitian. Data yang diperoleh dari penelitian ini, baik dari bahan hukum primer maupun bahan hukum sekunder, serta bahan hukum tersier dideskripsikan untuk kemudian dianalisis dengan cara kualitatif, yaitu dengan mempelajari, menganalisis serta menginterpretasikan setiap data yang telah dikumpulkan. Hasil analisis diuraikan dalam bentuk kalimat secara sistematis untuk memudahkan menarik kesimpulan dari data tersebut.

\section{Malapraktik Kedokteran}

Istilah "Malpractice" menurut Drs. Peter Salim dalam “The Contemporary English Indonesia Dictionary" berarti perbuatan atau tindakan yang salah. Malapraktik juga berarti praktik buruk (badpractice) yang menunjukkan ada setiap sikap tindak yang keliru. Sedangkan menurut John M. Echols dan Hassan Shadily dalam kamus Inggris Indonesianya, "Malpractice" berarti cara pengobatan pasien yang salah. Adapun ruang lingkupnya mencakup kurangnya kemampuan untuk melaksanakan kewajiban-kewajiban profesional atau didasarkan kepada kepercayaan. ${ }^{5}$

Dalam bahasa Belanda disebut dengan istilah "Kunstfout" (seni salah), merupakan suatu tindakan medis yang dilakukan tidak dengan sengaja akan tetapi di sini ada unsur lalai

3 Soerjono Soekanto dan Sri Mamudji, Penelitian Hukum Normatif: Suatu Tinjauan Singkat, 1 ed. (Jakarta: Rajawali Pers, 2014), 13.

4 Johan Nasution, Metode Penelitian Ilmu Hukum (Bandung: Mandar Maju, 2008), 96.

5 Ninik Mariyanti, Malpraktek Kedokteran (Dari Segi Hukum Pidana Dan Perdata) (Jakarta: Bina Aksara, 1988), 39. 
yang tidak patut dilakukan oleh seorang ahli dalam dunia medis dan tindakan mana yang mengakibat sesuatu hal yang fatal (misalnya mati atau cacat karena lalai).

Menurut Black's Law Dictionary, Malapraktik adalah setiap sikap tindak yang salah, kekurangan keterampilan dalam ukuran tingkat yang tidak wajar. Kegagalan untuk memberikan pelayanan dan melakukan pada ukuran tingkat keterampilan dan kepandaian yang wajar di dalam masyarakat oleh teman sejawat dari profesi itu sehingga mengakibatkan luka, kehilangan atau kerugian pada penerima pelayanan tersebut, termasuk di dalamnya setiap sikap tindak profesional yang salah, kekurangan keterampilan yang tidak wajar atau kekurang hati-hatian atau kewajiban hukum, praktik buruk atau ilegal atau sikap immoral.

Charles Wendell Carnahan dalam The Dentist and the Law, "Malpractice" yang diterjemahkan oleh Ninik Mariyanti menjelaskan Malapraktik adalah sebagai berikut:

"Malapraktik dalam arti umum, adalah praktik jahat atau buruk yang tidak memenuhi standar yang ditentukan oleh profesi. Dilihat dari sudut pasien yang telah dirugikan itu, meliputi kesalahan pemberian diagnosa, selama operasi dan sesudah perawatan".

Menurut Ninik Mariyanti bahwa malpractice itu sebenarnya mempunyai suatu pengertian yang luas yang dapat dibagi dua yaitu, dalam arti umum: suatu praktik khususnya praktik dokter yang buruk, yang tidak memenuhi standar yang telah ditentukan oleh profesi dan dalam arti khusus Malapraktik dapat terjadi dalam menentukan diagnosis, menjalankan operasi, selama menjalankan perawatan, dan sesudah perawatan dalam batas waktu tertentu. Kemudian Malapraktik di dalam kasus valentin v. Society se bienfaisance di Los Angeles, California tahun 1956 di definisikan sebagai kelalaian dari seorang dokter atau perawat untuk menerapkan tingkat keterampilan dan pengetahuannya di dalam memberikan pelayanan pengobatan dan perawatan terhadap seorang pasien yang lazimnya diterapkan dalam mengobati dan merawat orang sakit atau terluka di lingkungan wilayah yang sama. ${ }^{6}$

\section{Beban Pembuktian}

\subsection{Model Pembuktian Dalam Upaya Penanganan Malapraktik Medis di Indonesia}

Pembuktian dalam perkara pidana berbeda dengan pembuktian dalam perkara perdata. Pembuktian perkara pidana bertujuan untuk mencari kebenaran materil yaitu kebenaran yang sesungguhnya, sedangkan pembuktian perkara perdata adalah bertujuan untuk mencari kebenaran formil artinya hakim tidak boleh melampaui batas-batas yang diajukan oleh para pihak yang berperkara. Jadi hakim pidana jika mencari kebenaran

6 J. Guwandi, Hukum Medik (Jakarta: Balai Penerbit FKUI, 2007), 23. 
materiil dari suatu perkara, maka peristiwa tersebut harus terbukti atau dibuktikan (beyond reasonable doubt). ${ }^{7}$

Masalah pembuktian adalah hal yang sangat penting dan utama, terutama dalam kasus Malapraktik medis. Di Indonesia kasus-kasus Malapraktik terkadang tidak diselesaikan dengan memuaskan bahkan seolah para dokter sulit sekali untuk di buktikan telah melakukan Malapraktik medis secara hukum pidana. Pembuktian menurut Darwan Prints adalah pembuktian bahwa benar suatu peristiwa pidana telah terjadi dan terdakwalah yang bersalah melakukannya sehingga harus mempertanggungjawabkannya. ${ }^{8}$

Pembuktian dilakukan untuk memberikan kepastian kepada hakim tentang adanya suatu peristiwa atau perbuatan yang dilakukan oleh seseorang sehingga pembuktian dapat dijadikan dasar dalam menjatuhkan putusan oleh hakim. Sulitnya pembuktian pada kasus Malapraktik menyebabkan ada kasus-kasus Malapraktik yang sulit diajukan ke pengadilan dan hanya mengendap di laporan kepolisian saja.

Pembuktian pada kasus Malapraktik di Indonesia menggunakan cara yang sama seperti yang diatur oleh kitab undang-undang hukum acara pidana. Pembuktian dalam KUHAP menganut sistem atau teori pembuktian yang berdasarkan undang-undang secara negatif (negatief wettelijk). Seperti yang diatur pada Pasal 183 KUHAP bahwa hakim tidak boleh menjatuhkan pidana kepada seorang kecuali apabila dengan sekurang-kurangnya dua alat bukti yang sah ia memperoleh keyakinan bahwa suatu tindak pidana benar-benar terjadi dan bahwa terdakwalah yang bersalah melakukannya.

Menurut Wirjono Prodjodikoro, pembuktian berdasarkan undang-undang secara negatif sebaiknya dipertahankan berdasarkan dua alasan, yaitu: ${ }^{9}$

1) Memang selayaknya harus ada keyakinan hakim tentang kesalahan terdakwa untuk dapat menjatuhkan suatu hukuman pidana, janganlah hakim terpaksa memidana orang sedangkan hakim tidak yakin atas kesalahan terdakwa;

2) Berfaedah jika ada aturan yang mengikat hakim dalam menyusun keyakinannya, agar ada patokan-patokan tertentu yang harus dituruti oleh hakim dalam melakukan peradilan

Sehingga hakim terikat pada alat-alat bukti yang sah, yang artinya bahwa hakim hanya boleh mengambil keputusan berdasarkan alat-alat bukti yang ditentukan oleh undangundang saja.

Berdasarkan Pasal 184 ayat (1) KUHAP, bahwa yang termasuk alat bukti yang sah adalah: ${ }^{10}$

\footnotetext{
Andi Sofyan, Hukum Acara Pidana (Yogyakarta: Rangkang Education, 2013), 241.

Darwan Prints, Hukum Acara Pidana (Jakarta: LBH Jakarta, 1989), 106.

Wirjono Projodikoro, Hukum Acara Perdata di Indonesia (Bandung: Sumur Bandung, 1992), 114.

10 Republik Indonesia, Kitab Hukum Acara Pidana, UU Nomor 8 Tahun 1981, LN RI Nomor 76 Tahun 1981, TLN RI Nomor 3209.
} 
1. Keterangan saksi;

2. Keterangan ahli;

3. Surat;

4. Petunjuk;

5. Keterangan terdakwa.

Indonesia adalah suatu negara hukum seperti yang tercantum di dalam penjelasan Undang-Undang Dasar R.I. 1945. Dengan demikian maka asas-asas dan prinsip-prinsip suatu negara hukum harus dipegang teguh dan tidak bisa dikalahkan oleh kebutuhan sesaat, keadaan atau pikiran sewaktu-waktu. Di dalam suatu negara hukum yang memegang kekuasaan tertinggi adalah hukum, secara universal dinamakan "Rule of Law" dengan salah satu unsurnya yaitu asas praduga tak bersalah, seperti terdapat pada Pasal 66 KUHAP bahwa tersangka atau terdakwa tidak dibebani kewajiban pembuktian. Akan tetapi, Menurut J. Guwandi, Malapraktik Medis adalah jenis kasus yang khusus, dimana keahlian atau ilmu kedokteran sangat berbeda dengan ilmu hukum yang dikuasai oleh para penegak hukum, banyak keadaan-keadaan yang berbeda dan tidak bisa diprediksi yang bisa saja terjadi. ${ }^{11}$

Menggunakan pembuktian dengan cara yang diatur oleh KUHAP membuat para penegak hukum kesulitan menyelesaikan kasus Malapraktik medis, hal ini tentunya bisa memberi ketidakadilan bagi para pihak, baik tersangka atau korban. Pengetahuan terbatas aparat penegak hukum mengenai ilmu kedokteran membuat kasus Malapraktik sulit untuk diselesaikan. Di negara-negara Anglo Saxon seperti Amerika kasus Malapraktik tidak dapat dihindari, banyak kasus yang terjadi tetapi berbeda dengan Indonesia, kasus Malapraktik yang dilaporkan dapat diselesaikan di pengadilan karena mereka menggunakan pembuktian terbalik yang mempermudah mereka untuk menyelesaikan kasus Malapraktik tersebut. Penulis akan menjelaskan lebih lanjut mengenai pembuktian dalam upaya penanganan Malapraktik medis di Amerika.

\subsection{Model Pembuktian Dalam Upaya Penanganan Malapraktik Medis di Amerika}

Ternyata hukum medis di Negara Anglo Saxon sangat berkembang, hal ini dipengaruhi sistem hukum Anglo Saxon yang menjadikan hakim sebagai pusat utama perkembangan hukum melalui putusannya. Di negara Anglo Saxon termasuk Amerika Serikat dalam menyelesaikan kasus Malapraktik medis menerapkan asas res ipsa loquitur (the thing speaks for itself), doktrin ini berkaitan langsung dengan beban pembuktian. Dijelaskan bahwa "Res ipsa loquitur" tidak membuktikan sesuatu, ia tidak lain hanya suatu kemungkinan yang sangat terbatas untuk memindahkan beban pembuktian dari penggugat kepada tergugat. Penerapan doktrin ini tidak berlaku secara otomatis, hanya di dalam kasus-kasus tertentu dimana kesalahan seseorang sudah sedemikian jelasnya, sehingga secara langsung sudah dapat diketahui kesalahannya. Doktrin ini tidak dapat

11 J. Guwandi, Malpraktek Medik (Jakarta: Balai Penerbit FKUI, 2010), 5. 
diterapkan apabila ada tidaknya kelalaian masih tergantung kepada suatu hal yang bersifat relatif. 12

Dalam hal-hal tertentu kelalaian dokter sudah terlihat dengan jelas sehingga tidak usah ada pembuktian lagi karena bahkan orang awam pun sudah bisa mengetahui akan adanya suatu kelalaian sehingga tidak perlu bukti dari saksi ahli, kasus seperti inilah yang bisa menggunakan doktrin ini, sehingga dokter tersebutlah yang dibebankan untuk membuktikan bahwa dia tidak lalai, hal ini disebut pembuktian terbalik.

Di negara Anglo Saxon, memakai ukuran beban standar pembuktian, ada tiga yaitu: ${ }^{13}$

1. By a preponderance of evidence, bahwa harus terdapat bukti-bukti sedemikian rupa, sehingga apabila diukur ia mempunyai kekuatan yang lebih besar akan kebenarannya (lebih dari 50\%).

2. By clear and convincing evidence, yaitu tingkat ukuran bukti-bukti yang akan memberikan kesan kepada para juri tentang suatu tingkat ukuran kebenaran yang jelas dari apa yang dikemukakan oleh penggugat.

3. Beyond a resonable doubt, yaitu bahwa bukti-bukti itu harus benar-benar sudah berada dipihak penggugat, sehingga tidak ada kesangsian penilaian lagi terhadap pembelaan dari tergugat. Ukuran standar ini dipakai pada kasus-kasus kriminal.

Dari hal ini dapat kita lihat bahwa salah satu cara keberhasilan negara-negara Anglo Saxon menyelesaikan kasus Malapraktik medis utamanya Amerika. Di Amerika diterapkan pembuktian terbalik, dimana dalam negara yang menganut sistem Eropa kontinental seperti Indonesia mulanya dikatakan bahwa pembuktian terbalik melanggar asas praduga tak bersalah, padahal penerapan pembuktian terbalik itu sendiri dapat mewujudkan keadilan baik kepada tersangka maupun korban, karena bagaimanapun kedokteran adalah suatu bidang khusus yang menurut penulis tidak bisa diprediksi hasil akhirnya sehingga dokter yang dianggap melakukan Malapraktik dapat membuktikan bahwa dia tidak melakukannya dan hal ini membantu menyelesaikan kasus Malapraktik medis yang oleh aparat penegak hukum proses pembuktian untuk kasus ini adalah sulit, sehingga tidak dapat terselesaikan dengan baik.

Di negara Anglo Saxon, pembuktian terbalik diterapkan pada kasus yang bahkan orang awam pun tahu kalau itu adalah kelalaian dari dokter misalnya pada kasus Ybarra V. Spangard di California tahun 1944, seorang pasien menjalani operasi usus buntu, sesudah operasi malah pundaknya menjadi lumpuh, oleh hakim diterapkan doktrin "Res Ipsa Loquitur" atau dengan membalikkan beban pembuktian kepada mereka yang terlibat di dalam pembedahan tersebut, untuk mencari kebenaran apakah mereka benar melakukan kelalaian atau itu adalah risiko medis. ${ }^{14}$

12 Guwandi, Hukum Medik, 92.

13 Ibid., 98.

14 J. Guwandi, Dugaan Malpraktek Medik Dan Draft RPP:Perjanjian Terapetik Antara Dokter Dan Pasien (Jakarta: Balai Penerbit FKUI, 2006), 92. 
Kini pembalikan beban pembuktian sudah dikenal dalam Undang-undang Tindak Pidana Korupsi maupun Undang-undang Pencucian Uang di Indonesia, hal ini dapat diartikan bahwa paradigma tentang pembuktian terbalik yang melanggar asas praduga tak bersalah ini sudah berubah, bahwa pembuktian terbalik digunakan untuk memerangi ketidakadilan dan digunakan untuk urusan mendesak dimana pemerintah tidak berdaya mengatasi. Dari pengalaman-pengalaman yang dilalui Amerika Serikat dalam menangani kasus Malapraktik Medis sebenarnya Indonesia dapat mengikuti menerapkan Pembuktian terbalik untuk kasus Malapraktik di Indonesia.

\section{Dasar Peniadaan Perbuatan Malapraktik Medis}

\subsection{Dasar Peniadaan Perbuatan Malapraktik Medis di Indonesia}

Dasar peniadaan perbuatan di Indonesia termasuk ke dalam unsur perbuatan atau Actus Reus, unsur ini berhubungan langsung dengan pertanggungjawaban pidana, jika unsur ini tidak terpenuhi maka seseorang tidak dapat dimintai pertanggungjawaban pidana. Amir Ilyas dalam bukunya menguraikan unsur perbuatan (Actus Reus) sebagai berikut: ${ }^{15}$

- Mencocoki rumusan delik;

- Melawan hukum;

- Tidak ada alasan pembenar:

Tidak ada alasan pembenar dalam KUHP yaitu pada Pasal 48 KUHP tentang daya paksa absolut "Tidak dipidana seseorang yang melakukan perbuatan karena dorongan keadaan yang memaksa". Kedua, Pasal 49 ayat (1) KUHP tentang pembelaan terpaksa: "Tidak dipidana barang siapa yang melakukan perbuatan pembelaan terpaksa untuk diri sendiri atau orang lain, kehormatan kesusilaan atau harta benda sendiri atau orang lain, karena serangan sekejap itu atau ancaman serangan yang dekat pada saat itu yang melawan hukum". Ketiga, Pasal 50 ayat (1) KUHP yaitu menjalakan ketentuan undang-undang dan Keempat, Pasal 51 ayat (1) KUHP yaitu menjalankan perbuatan untuk melaksanakan perintah jabatan yang sah atau yang diberikan oleh penguasa yang berwenang. Ketentuan ini ditetapkan secara limitatif. Hal ini berarti bahwa selain yang ditetapkan oleh undangundang tersebut, tidak ada dasar lain yang digunakan.

Berbicara mengenai unsur ketiga atau dasar peniadaan pidana dalam hal ini alasan pembenar untuk suatu perbuatan, untuk penanganan atau penyelesaian kasus Malapraktik di Indonesia tidak ada bedanya dengan kasus-kasus lain seperti pencurian ataupun pembunuhan. Perundang-undangan di negara kontinental merupakan sumber utama dari hukum. Namun hukum tertulis itu dibuat pada suatu saat tertentu dan berdasarkan pada kondisi dan situasi pada saat itu, sedangkan masyarakat terus berkembang mengikuti kemajuan ilmu pengetahuan dan teknologi, alam pikiran, nilainilai dan norma di masyarakat pun turut mengalami perubahan. Dengan demikian

15 Amir Ilyas, Asas-Asas Hukum Pidana (Yogyakarta: Rangkang Education, 2012), 15. 
harusnya hukum jika ingin berkehendak adil, harusnya mengikuti perkembangan yang terjadi di masyarakat.

Terkadang suatu peraturan perundang-undangan dalam penerapannya untuk kondisikondisi khusus dianggap tidak memberikan keadilan. Misalnya berkaitan dengan dasar peniadaan pidana atau alasan pembenar yang diatur di dalam KUHP, dalam dunia kedokteran dimana jika seorang dokter melakukan tindakan medis yang secara yuridis memenuhi rumusan delik, jika terjadi kesalahan dalam tindakan medis yang diberikan, maka dokter dapat dikenakan pidana, padahal para pembuat undang-undang harusnya paham mengenai perkembangan ilmu pengetahuan dan teknologi serta memikirkan bahwa dalam praktik kedokteran terdapat "risiko" dimana hal ini terkadang tidak bisa di duga dan dikendalikan, oleh karena itu harusnya para pembuat undang-undang memperhatikan dan membuat aturan yang jelas mengenai aturan malapraktik medis di Indonesia, agar para dokter dan pasien mendapatkan keadilan sesuai dengan tujuan hukum itu sendiri.

\subsection{Dasar Peniadaan Perbuatan Malapraktik Medis di Amerika}

Di negara-negara Anglo Saxon seperti Amerika sudah berlaku dan berkembang di dalam yurisprudensi dan literatur hukum medis mengenai beberapa dasar peniadaan pidana yang khusus berlaku di bidang medis, karena harus diakui bahwa di dalam hukum medis terdapat beberapa faktor-faktor khusus yang tidak ditemukan di dalam hukum yang berlaku umum.

Dasar-dasar peniadaan perbuatan pada bidang medis adalah sebagai berikut: ${ }^{16}$

\section{Risiko dalam pengobatan}

a) Risiko yang melekat: pada setiap tindakan medis yang dilakukan oleh dokter, baik yang bersifat diagnostik maupun therapeutik akan selalu mengandung risiko yang melekat pada tindakan itu sendiri, risiko itu bisa timbul dan bisa juga tidak. Jika dokternya sudah bertindak hati-hati dan teliti berdasarkan prosedur standar profesi medis, maka ia tidak dapat dipersalahkan jika timbul suatu akibat yang tidak diduga atau tidak diinginkan.

b) Reaksi alergik: reaksi alergik adalah reaksi berlebihan dari tubuh seseorang karena alergi yang timbulnya secara tiba-tiba dan yang tidak dapat diprediksi terlebih dahulu. Oleh karenanya jika reaksi alergi tersebut kemudian timbul sehingga pasien mengalami anafilaktik shock, maka dokternya tidak dapat dipersalahkan.

c) Reaksi dari komplikasi dalam tubuh pasien: komplikasi yang timbul secara tiba-tiba pada diri pasien itu sendiri yang tidak bisa diketahui atau diduga sebelumnya, tidak dapat dipersalahkan kepada dokternya. Sering kali terjadi bahwa prognosis pasien tampak sudah baik, tetapi tiba-tiba keadaan pasien memburuk dan meninggal tanpa diketahui penyebabnya. Misalnya: sesudah

16 Guwandi, Hukum Medik, 104. 
menjalani suatu operasi dan dirawat untuk beberapa hari di ruangan, tiba-tiba timbul pulmonary emboli dan pasien meninggal.

2. Kekeliruan dalam penilaian klinis: error in judgment atau medical judgment atau istilah yang biasa dipakai adalah medical error, yaitu apabila seorang profesi medis yang telah mengikuti standar profesi yang dipakai secara umum tidak dapat dianggap lalai atau bertanggungjawab apabila keputusan yang diambil ternyata telah keliru.

3. Violenti non fit iniura: merupakan salah satu doktrin dalam ilmu hukum yang disebut sebagai "asumption of risk" atau adanya asumsi sudah diketahui adanya risiko besar pada orang yang bersangkutan. Ajaran ini digunakan dalam hukum medis pada tindakan-tindakan operasi yang mengandung risiko tinggi yang bisa menimbulkan akibat-akibat yang serius, maka dalam kasus-kasus semacam ini harus dijelaskan secara lengkap kepada pasien dan juga kepada orang lain yang berhubungan.

4. Contributory negligence: pada umumnya doktrin ini dipakai untuk menguraikan sikap-tindak atau perilaku yang tidak wajar pada pihak pasien, sehingga mengakibatkan cedera pada diri pasien itu sendiri.

Seperti yang telah diuraikan di atas, bahwa di Amerika melalui putusan-putusan hakimnya terdapat dasar pembenar yang secara khusus untuk kasus medis, dimana dalam dunia medis, risiko adalah sesuatu yang tidak dapat diprediksi dan selalu mengikuti setiap tindakan medis.

Di Indonesia aturan mengenai hukum medis terlihat belum berkembang, aturan-aturan mengenai ruang lingkup medis hanya diatur melalui beberapa undang-undang seperti Undang-Undang No. 29 Tahun 2004 tentang Praktik kedokteran akan tetapi undangundang terbaru tersebut juga tidak memberi penjelasan dan aturan mengenai apa itu malapraktik medis dan bagaimana dokter dapat dimintai pertanggungjawaban serta bagaimana proses peradilan yang dapat ditempuh untuk menegakkan keadilan. ${ }^{17}$

\section{Upaya Penanganan Malapraktik Medis}

\subsection{Penanganan Malapraktik Medis di Indonesia}

Di Indonesia untuk penegakkan hukum dalam kasus malapraktik medis digunakan aturan yang sama dengan tindak pidana umum yaitu menggunakan KUHAP dan KUHP sehingga ketentuan yang melekat adalah sama dengan ketentuan untuk penegakkan hukum dalam kasus-kasus tindak pidana lain seperti pencurian dan pembunuhan, padahal medis atau kedokteran merupakan cabang ilmu khusus yang sulit dipahami oleh orang awam apalagi para penegak hukum tidak disertai dengan pengetahuan yang kompleks mengenai medis.

Dalam hukum positif Indonesia seperti KUHP, Undang-Undang Nomor 36 Tahun 2009 tentang kesehatan maupun Undang-Undang Nomor 29 Tahun 2004 tentang Praktik Dokter Pasca putusan Mahkamah Konstitusi tidak diatur secara khusus atau tidak dikenal

17 Republik Indonesia, Praktik Kedokteran, UU Nomor 29 Tahun 2004, LN RI Nomor 116 Tahun 2004, TLN RI Nomor 4431. 
adanya istilah Malapraktik medis. Lembaga Bantuan Hukum Kesehatan menyatakan banyaknya kasus Malapraktik dokter di Indonesia adalah akibat sistem kesehatan yang tidak menunjang. Sejak 1999 hingga 2004, menurut data LBH Kesehatan sudah ada 126 kasus yang diduga Malapraktik. Kasus-kasus tersebut tidak semuanya diselesaikan di tingkat penyidikan atau laporan polisi. Kebanyakan, rumah sakit mau bertanggung jawab setelah pasien mendapat advokasi hukum. ${ }^{18}$ Menurut penulis kasus-kasus tersebut terjadi disebabkan karena lemahnya sistem perlindungan terhadap konsumen layanan kesehatan di Indonesia dalam hal ini yaitu pasien. Kemudian aparat penegak hukum yang awam dengan ilmu praktik kedokteran, medis atau ilmu tentang kesehatan.

\subsection{Penanganan Malapraktik Medis di Amerika Serikat}

Di Amerika dan negara Anglo Saxon lainnya pengaturan dan penegakkan hukum mengenai malapraktik medis ini sudah jauh lebih berkembang daripada di Indonesia, hal ini dapat terlihat dari aturan-aturan yang terdapat di negara-negara tersebut. Di Negara Amerika Serikat misalnya, tidak ada hukum kedokteran feodal yang berlaku untuk seluruh negara. Tiap-tiap negara bagian memiliki ketentuan-ketentuannya sendiri-sendiri di dalam mengadili dokter. Beberapa perangkat hukum kedokteran yang dikenal di Amerika Serikat adalah sebagai berikut: ${ }^{19}$

1. Liability Act. Merupakan perangkat hukum yang ketat, di sini dikenal ketentuan bahwa: bila seorang dokter telah bersedia menerima seorang pasien, maka ia sepenuhnya memikul tanggung jawab.

2. Good Samaritan Law. Dalam pasal tanggung jawab, hukum ini mempunyai penggarisan yang berbeda dengan Liability Act. Dalam hal keadaan darurat, tanggung jawab dokter tidak bisa dipaksakan. Artinya dalam keadaan gawat darurat, seorang dokter dibebaskan sama sekali dari kemungkinan tuntutan. Bahkan dari akibat Malapraktik, yang dianggap sangat mungkin terjadi karena daruratnya keadaan.

3. Medico Legal Consideration. Kumpulan ketentuan hukum di sini sangat rumit dan masuk dalam bidang teknis kedokteran. Tujuannya adalah untuk melindungi dokter dari Malapraktik yang tidak bisa dihindari oleh dokter. Jadi bukan karena kealpaan tetapi karena ilmu kedokterannya sendiri memang belum bisa menjamin keberhasilan suatu praktik.

Medico Legal Consideration mempunyai klausul yang mengharuskan dokter untuk hatihati, khususnya dalam memutuskan untuk melakukan pembedahan elektif atau yang tidak mendesak, ia harus mendapatkan rekomendasi dari sekurang-kurangnya seorang dokter lain. Maka bila seorang ahli bedah berani memutuskan sendiri sebuah operasi elektif, walaupun itu berhasil tetap dianggap telah melanggar hukum. Walaupun si pasien tidak menuntut, dokter tersebut tetap akan diajukan ke pengadilan.

18 Yophiandi, “LBH Kesehatan: Pasien di Indonesia Tak Terlindungi,” Tempo News Room, diakses November 17, 2019, https://metro.tempo.co/read/45022/lbh-kesehatan-pasien-di-indonesia-tak-terlindungi.

19 Mariyanti, Malpraktek Kedokteran (Dari Segi Hukum Pidana Dan Perdata), 66. 
Dari Amerika, seharusnya Indonesia dapat mencontoh bahwa kesuksesan Amerika dalam menangani ribuan kasus Malapraktik yang masuk ke pengadilan mereka adalah karena di dasari dengan aturan yang jelas. Indonesia, untuk melindungi para masyarakat dari Malapraktik yang dapat merugikan bahkan mengancam nyawa, serta untuk melindungi dokter dari dugaan Malapraktik dan pembuktian yang tidak jelas di pemeriksaan maupun pengadilan, seharusnya Indonesia membentuk aturan jelas dan mendefinisikan apa yang dimaksud dengan Malapraktik medis. Kemudian para penegak hukum juga diberi pengetahuan mengenai bagaimana menangani Malapraktik medis, seperti di Amerika. Di Amerika para penegak hukum sudah tahu bagaimana "aturan main", "bagaimana menyeret dokter ke pengadilan" karena ilmu medis merupakan suatu ilmu khusus yang sulit untuk dipahami oleh orang non-medis, jadi upaya menaikkan kualitas penegak hukum merupakan langkah awal yang bagus jika ingin memajukan penegakkan hukum medis. Jika ini merupakan hal yang sulit dilakukan, menurut penulis harusnya ada lembaga investigasi khusus yang dibentuk untuk menilai apakah perbuatan tersebut merupakan Malapraktik medis dan dapat diajukan ke pengadilan, hal ini dilakukan untuk mewujudkan keadilan tidak hanya bagi para pasien tapi para dokter yang memang dalam pekerjaannya memiliki risiko yang tidak bisa dia prediksi.

\section{Kesimpulan}

Pembuktian pada kasus Malapraktik di Indonesia menggunakan cara yang sama seperti yang diatur oleh kitab undang-undang hukum acara pidana. Pembuktian dalam KUHAP menganut sistem atau teori pembuktian yang berdasarkan undang-undang secara negatif (negatief wettelijk). Sedangkan di negara Anglo Saxon termasuk Amerika Serikat dalam menyelesaikan kasus Malapraktik medis menerapkan asas res ipsa loquitur (the thing speaks for itself), doktrin ini berkaitan langsung dengan beban pembuktian. "Res ipsa loquitur" tidak membuktikan sesuatu, ia tidak lain hanya suatu kemungkinan yang sangat terbatas untuk memindahkan beban pembuktian dari penggugat kepada tergugat atau menggunakan pembuktian terbalik. Berbicara mengenai unsur ketiga atau dasar peniadaan pidana dalam hal ini alasan pembenar untuk suatu perbuatan, untuk kasus Malapraktik di Indonesia tidak ada bedanya dengan kasus-kasus lain seperti pencurian ataupun pembunuhan yaitu seperti di atur pada Pasal 48-50 ayat (1) KUHAP, Sedangkan di Amerika sudah berlaku dan berkembang di dalam yurisprudensi dan literatur hukum medis mengenai beberapa dasar peniadaan pidana yang khusus berlaku di bidang medis, yaitu Risiko dalam pengobatan (Risk of treatment), Risiko yang melekat (Inherent risks), Risiko dari akibat reaksi alergik, Risiko komplikasi yang timbul dalam tubuh seseorang pasien, Kecelakaan (mishap, accident, misadventure, mischance), Kekeliruan dalam penilaian (Non-negligent error of clinical judgement), Violenti non fit iniura, dan Contributory negligence.

Di Indonesia untuk penegakkan hukum dalam kasus malapraktik medis digunakan aturan yang sama dengan tindak pidana umum yaitu menggunakan KUHAP dan KUHP sehingga ketentuan yang melekat adalah sama dengan ketentuan untuk penegakkan hukum dalam kasus-kasus tindak pidana lain seperti pencurian dan pembunuhan, padahal medis atau 
kedokteran merupakan cabang ilmu khusus yang sulit dipahami oleh orang awam apalagi para penegak hukum tidak disertai dengan pengetahuan yang kompleks mengenai medis. Dalam hukum positif Indonesia baik KUHP, Undang-Undang Nomor 36 Tahun 2009 tentang kesehatan, Undang-Undang Nomor 29 Tahun 2004 tentang Praktik Dokter Pasca putusan Mahkamah Konstitusi tidak diatur secara khusus atau tidak dikenal adanya istilah Malapraktik medis, sedangkan di Amerika dan negara Anglo Saxon lainnya pengaturan dan penegakkan hukum mengenai malapraktik medis sudah jauh lebih berkembang di Indonesia, hal ini dapat terlihat dari aturan-aturan yang terdapat di negara-negara tersebut. Di Negara Amerika Serikat tidak ada hukum kedokteran feodal yang berlaku untuk seluruh negara. Tiap-tiap negara bagian memiliki ketentuan-ketentuannya sendirisendiri di dalam mengadili dokter. Beberapa perangkat hukum kedokteran yang dikenal di Amerika Serikat yaitu Liability Act, Good Samaritan Law dan Medico Legal Consideration.

\section{Daftar Pustaka}

Ardianingtyas, dan Charles M. Tampubolon. "Kesalahan Diagnosis Dokter: Tergolong Malpraktek atau Kelalaian." HukumOnline.com. Diakses November 17, 2019. https://www.hukumonline.com/berita/baca/hol10135/kesalahan-diagnosisdokter-tergolong-malpraktek-atau-kelalaian-medikkah/.

Dirdjosisworo, Soedjono. Pengantar Ilmu Hukum. Jakarta: RajaGrafindo, 2010.

Guwandi, J. Dugaan Malpraktek Medik Dan Draft RPP:Perjanjian Terapetik Antara Dokter Dan Pasien. Jakarta: Balai Penerbit FKUI, 2006.

_—_. Hukum Medik. Jakarta: Balai Penerbit FKUI, 2007.

——_. Malpraktek Medik. Jakarta: Balai Penerbit FKUI, 2010.

Ilyas, Amir. Asas-Asas Hukum Pidana. Yogyakarta: Rangkang Education, 2012.

Mariyanti, Ninik. Malpraktek Kedokteran (Dari Segi Hukum Pidana Dan Perdata). Jakarta: Bina Aksara, 1988.

Nasution, Johan. Metode Penelitian Ilmu Hukum. Bandung: Mandar Maju, 2008.

Prints, Darwan. Hukum Acara Pidana. Jakarta: LBH Jakarta, 1989.

Projodikoro, Wirjono. Hukum Acara Perdata di Indonesia. Bandung: Sumur Bandung, 1992.

Soekanto, Soerjono, dan Sri Mamudji. Penelitian Hukum Normatif: Suatu Tinjauan Singkat. 1 ed. Jakarta: Rajawali Pers, 2014.

Sofyan, Andi. Hukum Acara Pidana. Yogyakarta: Rangkang Education, 2013.

Yophiandi. "LBH Kesehatan: Pasien di Indonesia Tak Terlindungi." Tempo News Room. Diakses November 17, 2019. https://metro.tempo.co/read/45022/lbh-kesehatanpasien-di-indonesia-tak-terlindungi. 